\title{
2 Dental casting alloys behaviour during power toothbrushing 3 with toothpastes of various abrasivities. Part II: corrosion and ion release
}

\author{
C. Molina $\cdot$ Ll. Nogués $\cdot$ J. Martinez-Gomis $\cdot$ M. Peraire $\cdot$
}

9 Abstract The purpose of this study was to evaluate the 10 long term effect of abrasivity of toothpastes normally used 11 over the corrosion behavior and ion release of the different 12 dental casting alloys. Three dental casting alloys $(\mathrm{Ni}-\mathrm{Cr}$, $13 \mathrm{Co}-\mathrm{Cr}$ and commercially pure $\mathrm{Ti}$ ) were studied. Four spec14 imens of each material were immersed, brushed without 15 paste or brushed with one of four toothpastes of different 16 Relative Dentine Abrasivity (RDA 50, 52, 80, and 114). An 17 electric toothbrush with a load of $250 \mathrm{~g}$ was used for $18420 \mathrm{~min}$. Corrosion behavior was determined by means a 19 potenciostat with high sensitivity and the ion release deter20 mined by Inductively Coupled Plasma-Mass Spectrometry. 21 Two-way ANOVA and non-parametric tests were used to 22 detect significant differences. Titanium specimens exhibited the best corrosion behavior after and before the toothbrushed, being the worst of the three alloys the $\mathrm{Cr}-\mathrm{Ni}$. Titanium oxide produced spontaneously on the Ti surface is the main cause of the high corrosion resistance of the material. However, the eutectoid of the $\mathrm{CrNi}$ with chemical composition between different phases produces pitting on the phases boundaries with an important decrease of the

C. Molina · Ll. Nogués · J. Martinez-Gomis · M. Peraire · J. Salsench - F. J. Gil

Faculty of Dentistry, Department of Prosthodontics, Universitat de Barcelona, Barcelona, Spain

\section{P. Sevilla}

Catalonia Bioengineering Institute (IBEC), Department of Materials Science and Metallurgical Engineering, Universitat Politècnica de Catalunya, Barcelona, Spain

\section{F. J. Gil ( $\square)$}

Department of Materials Science and Metallurgical Engineering, ETSEIB, Universitat Politècnica de Catalunya, Av. Diagonal 647, 08028 Barcelona, Spain

e-mail: francesc.xavier.gil@upc.edu corrosion resistance. Besides, the $\mathrm{CrNi}$ produces high values of the $\mathrm{Ni}$ and $\mathrm{Cr}$ release. Slight increment in roughness were observed after toothbrushing and depended on the material but not on the toothpaste used. The increase of the microhardness (residual stresses) provokes a decrease of the corrosion resistance and an increase of the ion release.

\section{Introduction}

Corrosion may be described as the deterioration of materials by aggressive action of the environment (atmosphere and oral fluids). This term is used for metals, and the mechanism of corrosion is mainly electrochemical. Corrosion is said to be continuous in the mouth, because these ions are removed with the abrasion of foods, liquids and toothbrushes [1-3].

Corrosion of dental alloys may result in biological, functional and aesthetic effects. Besides, in corrosion processes metal ions are released and may come into contact with cells and tissues in the immediate environment, or be distributed throughout the body, mainly to the intestine canal. If these ions are not biocompatible, then the organism may be injured (toxicity and risk of sensitization) if they are absorbed in sufficient quantity [4-7].

In vitro electrochemical techniques have been proven to be sufficiently sensitive to measure even a low corrosion rate; moreover, they are quick and convenient and are now used by many researchers $[1,5,6]$, although the clinical relevance of these techniques is heavily debated.

The aim of this study is to evaluate, in vitro, the effect of toothbrushing on ion release and corrosion resistance of different dental alloys using rotation oscillating toothbrushing and different toothpastes in artificial saliva. 


\section{Material and methods}

The materials and treatments realized were the same of the Part I of this work.

The schematic electrical set-up used to measure the electrochemical parameters is shown in Fig. 1. The corrosion cell used is a glass cell with the working electrodes and a saturated $\mathrm{Ag} / \mathrm{AgCl}$ electrode used as a reference (VidraFoc Spain). The distance from the reference electrode to samples was $25 \mathrm{~mm}$. The ratio of anode surface to the cathode surface was equal to one. Dental alloys were kept immersed in the electrolyte for all the measurements taken. The electrolyte is artificial saliva at a temperature of $37^{\circ} \mathrm{C}$ and $\mathrm{pH} 6.7$ with the composition given in the Table 1. The electrolyte is changed for each experiment. The corrosion tests were realized before and after of the abrasive treatment, described in Part I.

The current versus time in the galvanic coupling studied was controlled by a Hewlett Packard potentiostat (USA). The variation of the potentials in an open short circuit was controlled by a Digital Multimeter \& Scanner Resistance (Volatalab Radiometer, France). Using this type of assembly it is possible to measure at the same time the current and the common potential (short potential) versus time of the galvanic coupling studied. More or less similar

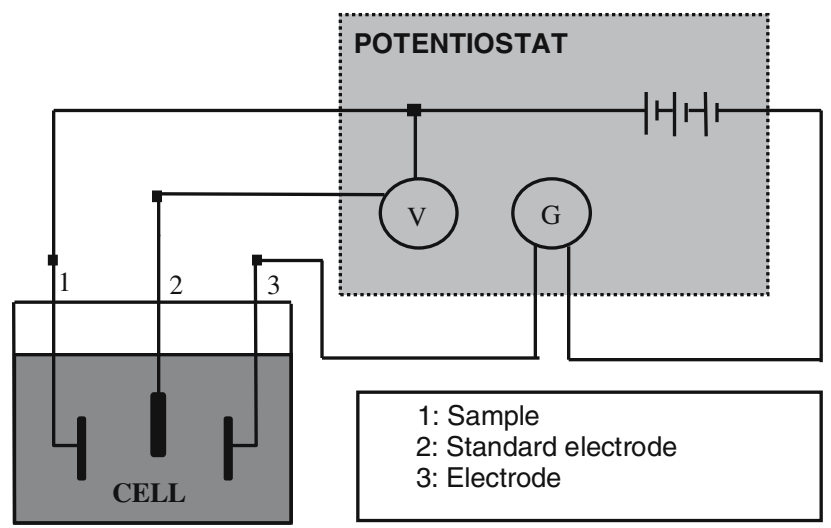

Fig. 1 Schematic electrical set-up used to measure the electrochemical parameters

\begin{tabular}{lll} 
Table 1 Chemical composition & & \\
\cline { 2 - 3 } of the artificial saliva & Compound & $\begin{array}{l}\text { Composition } \\
\left(\mathrm{g} / \mathrm{dm}^{3}\right)\end{array}$ \\
\cline { 2 - 3 } & $\mathrm{K}_{2} \mathrm{HPO}_{4}$ & 0.20 \\
$\mathrm{KCl}$ & 1.20 \\
$\mathrm{KSCN}$ & 0.33 \\
$\mathrm{Na}_{2} \mathrm{HPO}_{4}$ & 0.26 \\
& $\mathrm{NaCl}$ & 0.70 \\
& $\mathrm{NaHCO}_{3}$ & 1.50 \\
& Urea & 1.50 \\
& Lactic acid & Until $\mathrm{pH}=6.7$ \\
\hline
\end{tabular}

assemblies were used by other authors in measurements of Evans diagrams of galvanic couplings [6, 8-11]. The overall system was controlled using PC-compatible computer. The preparations of the samples and the corrosion test carried out followed the ASTM standards G8 and G15 [12].

The specimens were subjected to the following measuring cycle:

- Immersion in the de-aerated electrolyte for $250 \mathrm{~min}$ with recording of the open potential of each electrode.

- By means of a potentiostat the potential at intervals of $50 \mathrm{mV}$ until $1.6 \mathrm{~V}$ was increased. Recordings of the variation of the galvanic current density, potential, etc. were obtained and the Tafel slopes were determined from the Evanś diagrams. In order to determine these diagrams, it is very important to record the polarization curves in a pseudostationary manner. In this study, the $250 \mathrm{~min}$ of immersion of specimens was regarded sufficient.

The microstructure of the different dental materials was observed before corrosion processes by optical microscopy (MEF 4.Olympus, Japan). The corroded surfaces were observed by scanning electron microscopy (JEOL 6400, Japan) in order to observe the pitting zones and by means of X-ray dispersive energy microanalysis (Lynk, USA) to determine the chemical composition of the places more prone to corrosion.

Ten millilitres of solution was extracted before the tooth brushed in order to analyse the metallic ions released. The container was perfectly protected in order that no impurity interfered with the results. The quantification of the ions released was carried out by ICP-MS measurement (Inductively Coupled Plasma-Mass Spectrometry) (IZASA. Spain).

\section{Results and discussion}

Five specimens of each alloy were tested by electrochemical methods. Each specimen was polarized five times and polished before the tests, then the mean values were calculated: the critical current density $\left(i_{c r}\right)$, the passive current density $\left(i_{p}\right)$, the corrosion potential $\left(E_{\text {corr }}\right)$ and the critical pitting potential $\left(\mathrm{E}_{\mathrm{cp}}\right)$, as can be observe in Table 2 for each system (material-paste with different RDA). The light increase of microhardness produces a decrease of the corrosion resistance due to the increase of the surface residual stress by the abrasion process [13, 14]. The different polarization tests for each sample do not showed changes in the results for the different magnitudes.

The material with higher current density at a given potential, is the more prone to corrode. Cp Titanium had 
136 the most passive $\left(0.85 \mu \mathrm{A} / \mathrm{cm}^{2}\right)$ and Nickel-Chromium alloy had the most active $\left(1.9 \mu \mathrm{A} / \mathrm{cm}^{2}\right)$ critical current density values. The value for the CoCr was $1.11 \mu \mathrm{A} / \mathrm{cm}^{2}$. If passive current density is low, the alloy is said to passivate more easily. The passive current density values were $0.68 \mu \mathrm{A} / \mathrm{cm}^{2}$ for the Titanium, $0.80 \mu \mathrm{A} / \mathrm{cm}^{2}$ for $\mathrm{CoCr}$ and $1.00 \mu \mathrm{A} / \mathrm{cm}^{2}$ for $\mathrm{Ni}-\mathrm{Cr}$ alloy was the most active alloy, with a pitting potential value of $+90 \mathrm{mV}$. This potential is $+443 \mathrm{mV}$ for $\mathrm{CoCr}$ and $+555 \mathrm{mV}$ for cp Ti $[1,15]$.

Titanium is one of the most corrosion-resistant materials used for biomedical applications. The oxide that forms on titanium provides the corrosion resistance under static conditions, and it has often been reported that titanium is not susceptible to pitting and/or crevice corrosion phenomena [16].

In all the cases, the current density increases and the corrosion potential decrease significatively when the abrasivity of the toothpaste is bigger (Table 2). This abrasivity increases the surface microhardness due to the internal stresses produced in the surface of the titanium brushed that favor the corrosion processes [17].

In the other hand, chromium is added to the nickel-based alloys to improve the alloy's ability to form a protective oxide film on the surface. It has been suggested that chromium content from $16 \%$ to $27 \%$ will provide an optimum corrosion resistance for the nickel-based alloys, while the addition of molybdenum will also further enhances the corrosion resistance [17-19]. Alloys with lower chromium content may not be able to develop oxide films adequate for corrosion resistance. The microstructure of the nickelchromium alloy before corrosion test is shown in the Fig. 2. This reveals its dendritic structure and an eutectic phase, which is susceptible to preferential corrosion [20]. It can be observed in the Scanning Electron Microscopy that an etched surface is showing corrosion of the preferential phase of the eutectic and thus a disruption of the oxide film (Fig. 2). This alloy presents localized corrosion phenomena. The phases formed by the minor alloying elements have been shown to

\begin{tabular}{|c|c|c|c|c|c|c|}
\hline Alloys & Microhard. (HVN) & $\mathrm{E}_{\text {nat }}(\mathrm{mV})$ & $\mathrm{i}_{\mathrm{cr}}\left(\mu \mathrm{A} / \mathrm{cm}^{2}\right)$ & $\mathrm{i}_{\mathrm{p}}\left(\mu \mathrm{A} / \mathrm{cm}^{2}\right)$ & $\mathrm{E}_{\mathrm{CORR}}(\mathrm{mV})$ & $\mathrm{E}_{\mathrm{cp}}(\mathrm{mV})$ \\
\hline $\mathrm{Ti}$ & 480.5 & 0.024 & 0.85 & 0.68 & -20 & +555 \\
\hline Ti abraded RDA 50 & 499.0 & 0.022 & 1.02 & 0.78 & -30 & +550 \\
\hline Ti abraded RDA 52 & 503.2 & 0.020 & 1.15 & 0.82 & -32 & +540 \\
\hline Ti abraded RDA 80 & 510.2 & 0.019 & 1.19 & 0.85 & -35 & +536 \\
\hline Ti abraded RDA 114 & 515.6 & 0.016 & 1.21 & 0.90 & -41 & +530 \\
\hline $\mathrm{CrCo}$ & 527.8 & -0.121 & 1.11 & 0.80 & -45 & +443 \\
\hline CoCr abraded RDA 50 & 543.2 & -0.223 & 1.21 & 0.90 & -52 & +343 \\
\hline CoCr abraded RDA 52 & 545.0 & -0.225 & 1.31 & 0.95 & -55 & +312 \\
\hline CoCr abraded RDA 80 & 550.1 & -0.235 & 1.43 & 0.99 & -62 & +301 \\
\hline CrCo abraded RDA 114 & 559.2 & -0.289 & 1.56 & 1.10 & -71 & +298 \\
\hline $\mathrm{NiCr}$ & 312.7 & -0.130 & 1.90 & 1.00 & -100 & +90 \\
\hline $\mathrm{NiCr}$ abraded RDA 50 & 339.6 & -0.144 & 1.99 & 1.20 & -110 & +78 \\
\hline $\mathrm{NiCr}$ abraded RDA 52 & 340.2 & -0.158 & 2.08 & 1.25 & -125 & +69 \\
\hline NiCr abraded RDA 80 & 351.6 & -0.168 & 2.14 & 1.30 & -130 & +60 \\
\hline NiCo abraded RDA 114 & 370.0 & -0.171 & 2.30 & 1.33 & -134 & +58 \\
\hline
\end{tabular}

Fig. 2 Microstructure of $\mathrm{NiCr}$ alloy

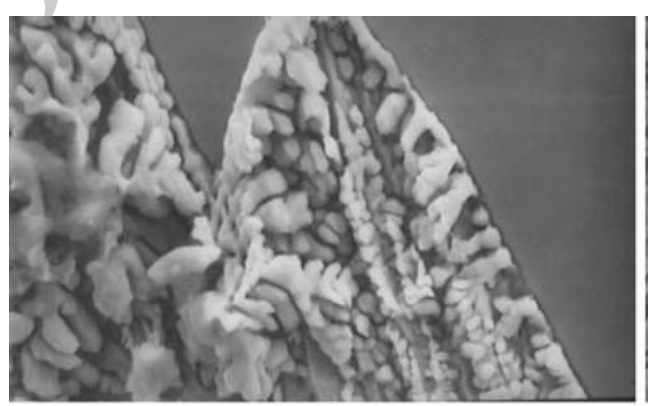

$10 \mu \mathrm{m}$
Table 2 Corrosion parameters analysed for the different metals and alloys with different toothpastes

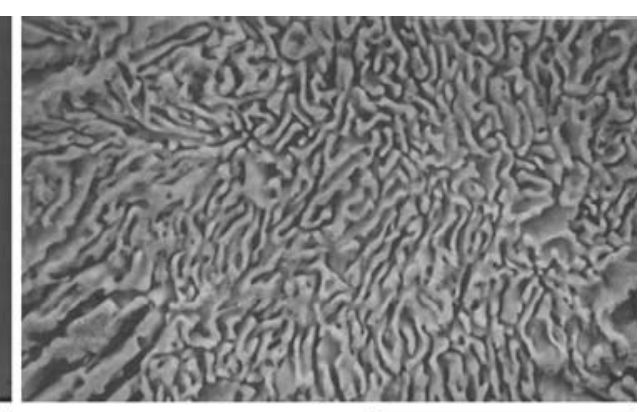

$10 \mu \mathrm{m}$ 
have a significant effect on the corrosion properties of the nickel-based alloys [20]. The corrosion results can be observed in Fig. 3 for the NiCr alloy brushed. Ti and $\mathrm{CrCo}$ present only one phase in their microstructures and consequently there are not differences in the chemical composition in the material. This fact produces an important increase in the corrosion behavior.

The results of the ion release are shown from Fig. 4. It should be emphasized, in the first place, that the ion release in the titanium material does not reach $40 \mathrm{ppb}$ after tooth brushed. This low release is due to the passivating film of titanium oxide (inert coating) that reduces the metallic ion diffusion to the external environment [21].

In relation to the Nickel-Chromium alloy produces the largest amount of ion release, as can be appreciated in

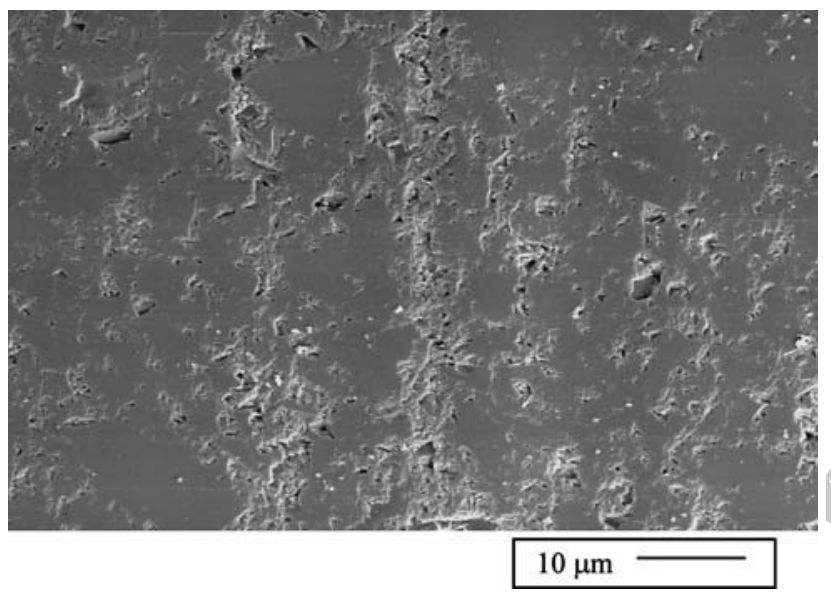

Fig. 3 Corrosion localized for the $\mathrm{NiCr}$ alloy

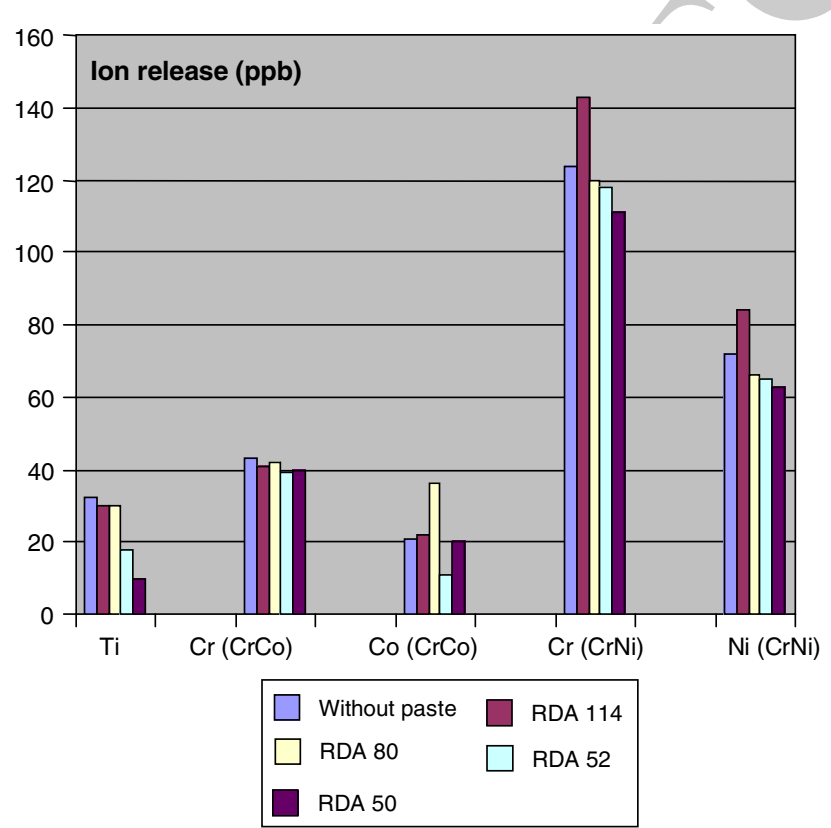

Fig. 4 Ion release for each alloy and toothpaste used
Fig. 4. This greater ion release in the environment can be justified because this alloy presents the least resistance to corrosion and accordingly presents a larger amount of products of corrosion released to the environment [22].

The Nickel-Chromium alloy microstructure is not single phase and accordingly does not present chemical homogeneity in all its structure like the other alloys studied. The Chromium-Nickel alloy presents solidification dendrites and around these a laminar eutectic structure. This means in effect that there are plates one beside the other with a different chemical composition, so accordingly the structure acts as if it were an electrochemical cell [23]. The alloy should be chemically homogenized at high temperature to improve the performance against corrosion and the ion release of the alloy, followed by a rapid cooling to avoid metallic diffusion and to produce a chemically homogeneous structure.

Although the quantity of $\mathrm{Ni}$ ions released is much below the $300-500 \mu \mathrm{g}$ corresponding to the critical concentration to induce allergy [24], even in the case of untreated surfaces, this quantity might be enough to induce long-term inflammatory responses or alter cells behavior. Sun et al. [25] showed that even at subtoxic concentrations, metal ions can alter osteoblast behavior. For Ni ions, a significant decrease in Alkaline Phosphatase Activity (ALP) and DNA synthesis has been observed. Other works have shown that $\mathrm{Ni}$ ions could be responsible for inducing the secretion of different cytokines involved in the inflammatory process. Wataha et al. [26] observed an increase of IL1 $\beta$ secretion by macrophages at $\mathrm{Ni}$ concentrations known to be released by NiTi dental materials. Moreover, in another study [27], they also demonstrated that the quantity of IL $1 \beta$ secreted from monocytes due to $\mathrm{Ni}$ ions release $(7.2 \mu \mathrm{g} / \mathrm{ml})$ was sufficient to indirectly induce ICAM1 (Intracellular Adhesion Molecules that are involved in the recruitment of other inflammatory cells) secretion on endothelial cells. Finally, Cederbrant et al. [28] showed that even a quantity as small as $1.2 \mu \mathrm{g} / \mathrm{ml}$ of $\mathrm{Ni}$ could induce an increase in lymphocytes proliferation and IL10 secretion in subjects allergic to Ni. Thus, the results obtained might be of great importance to improve the long-term biocompatibility properties of the material and to reduce sensitization to $\mathrm{Ni}$ and allergies.

Acknowledgements The authors are grateful to CICYT for the financial support of this study.

\section{References}

1. J. Geis-Gerstorfer, J. Dent. 22, 247-251 (1994)

2. P. Branemark, I. Hansson, R. Adell, U. Lindstrom, J. Hallen, O. Ohman, Scand. J. Plast. Reconstr. Surg. 11(Supp1), 16 (1977) 
3. R. Adell, U. Lekholm, U. Rocker, P. Branemark, Int. J. Oral Surg. 6, 387-416 (1981)

4. P. Branemark, R. Adell, T. Albrektsson, Adv. Biomater. 4, 133-141 (1982)

5. I. Ericsson, U. Lekholm, P. Branemark, J. Lindhe, P.O. Glantz, S. Nyman, J. Clin. Periodontol. 13, 307-312 (1986)

6. L. Reclaru, J.M Meyer, J. Dent. 22, 159-168 (1994)

7. N.K. Sarkar, R.A. Fuys, J.W. Stanford. Applications of electrochemical techniques to characterize the corrosion of dental alloys, in Corrosion and Degradation of Implant Materials, ed. by B.C. Syrett, A. Acharya (ASTM, 1979), pp. 277-294

8. D. Brune, Biomaterials 7, 163-175 (1996)

9. J. Lee, L.C. Lucas, J. O’neal, W. Lacefield, J.E. Lemons, J. Dent. Res. 64, 317 (1985)

10. H. Hero, J. Valderhang, R.B. Jorgensen, Dent. Mater. 3, 324-328 (1987)

11. B.I. Johansson, L.C. Lucas, J.E. Lemons, J. Biomed. Mater Res. 23, 349-361 (1989)

12. Annual Book of ASTM Standards. Metals Test Methods and Analytical Procedures. Wear and Corrosion; Metal Corrosion. 3.02 (1992), pp. 56-85

13. C. Aparicio, F.J. Gil, C. Fonseca, M. Barbosa, J.A. Planell, Bioamterials 24, 263-273 (2003)

14. M. Vallet-Regí, I. Izquierdo-Barba, F.J. Gil, J Biomed. Marter. Res. 67, 674-678 (2003)
15. L. Reclaru, J.M Meyer, J. Dent. 22, 159-168 (1994) 263

16. F.J. Gil, M.P. Ginebra, J.A. Planell, J. Biomed. Mater. Eng. 12, 264 271-281 (2002)

17. L.C. Lucas, J.E. Lemons, Adv. Dent. Res. 6, 32-37 (1992)

18. T.K. Vaidyanathan, A. Prasad, J. Dent. Res. 60, 707-715 (1981) 267

19. M. Maredlk, Corrosion in a biological environment. In: Bio- 268 compatibility, toxicity, and hypersensitivity to alloy systems used 269 in dentistry. Ann. Arbor (MI). The University of Michigan School 270 of Dentistry (1986), pp. 103-122

20. L. Gettleman, F.H. Coks, L.A. Darmiento, P.A. Levine, 272 S. Wright, J. Dent. Res. 59, 689-707 (1980) 273

21. D. Rodriguez, F.J. Gil, E. Jorge, A. Zapata, J.A. Planell, J. Mater. 274 Sci Mater. Med. 10(12), 847-852 (1999) 275

22. J. Lee, L. Lucas, J. O'neal, W. Lacefield, J. Lemons, J. Dent. Res. 276 64, 317 (1985)

23. S. Canay, M. Öktemer, J. Dent. Res. 23(4), 279-287 (1992)

24. H.H. Huang, Y.H. Chiu, T.H. Lee, S.C. Wu, H.W. Yang, K.H. Su, 279 C.C. Hsu, Biomaterials 25, 3585-3592 (2003) 280

25. Z.L. Sun, J.C. Wataha, J. Biomed. Mater. Res. 34, 29-37 (1997) 281

26. J.C. Wataha, S. Ratanasathienz, C.T. Hank, Z. Sun, Dental Mater. 282 12, 322-327 (1996) 283

27. J.C. Wataha, P.E. Lockwood, M. Marek, M. Ghazi, J Biomed 284 Mater Res. 45, 251-257 (1999) 